\title{
Geoelectric Investigation of the Suitability of a Proposed Foldot Ventures Potable Water Factory Site, Ipinsa, near Akure, Southwestern Nigeria
}

\author{
I. A. Adeyemo \\ Department of Applied Geophysics, Federal University of Technology, Akure, Nigeria \\ [E-mail: iaadeyemo@futa.edu.ng; $\mathbf{P}:+2348060042770]$
}

\begin{abstract}
This study is aim at determining the suitability of sitting a potable water factory within Chief Akin Omosebi layout off Ipinsa-llara road, near Akure, Ondo State, Nigeria by evaluating the groundwater potential, the aquifer overlying layer protective capacity and the foundation beds competence of the area. A total of twenty (20) vertical electrical soundings (VES) data were acquired along five (5) traverses using Schlumberger array with maximum half-current electrode separation of $150 \mathrm{~m}$. Three curve types were delineated in the area (K, KH and KQ). The VES results delineated three to four geoelectric layers across the study area. The resistivity of the top soil, lateritic weathered layer, clayey sand weathered layer and weathered bedrock/fresh bedrock varies from 187 - 1212, 682 4164, 219 - 1157 and 77 - 3525 ohm-m respectively. This study reveals that the area is characterized by high groundwater potential and competent subsurface layers that can serve as foundation bed, but the aquifer layer must be well protected from pollution since the overlying layer(s) longitudinal conductance is less than 1.0 mhos which indicates that the underlying aquifer unit(s) are vulnerable to surface pollution.
\end{abstract}

Keywords: Groundwater potential, aquifer overlying layer, protective capacity, longitudinal conductance and foundation beds competence.

\section{INTRODUCTION}

Provision of potable water supply are not been given serious attention in many developing countries of the world, perhaps this is due to infrastructural deficits arising from poor economic state of such countries. Nigeria been a developing countries where commercial production of potable water is a fast growing industry, since most citizens who cannot afford boreholes results into purchase of sachet and bottled water for their daily water consumptions. However for potable water factory to be situated at a particular location two important criteria must be met: The area must have high groundwater potential (Mogaji et al., 2011; Olayanju et al., 2011 and Adeyemo et. al., 2017a) and the aquifer layer must be well protected from pollution and contamination (Oladapo, 2004; Aweto, 2011 and Oni et al., 2017). Presence of good competent subsurface layer(s) is also desirable for the construction of the potable water factory. This study was carried out to determine the suitability of the study area as a good location for sitting the proposed Foldot Ventures Nigeria enterprises' potable water factory. Groundwater potential evaluation have been carried out in crystalline basement complex terrain using different approaches such as isolated analyses of some hydrogeophysical significant parameters, such as overburden thickness, aquifer resistivity, aquifer thickness and bedrock relief (Amadi et al., 2011; Mogaji et al., 2011; Olayanju et al., 2011; Akintorinwa and Olowolafe, 2013 and Adeyemo et. al., 2017a) and application of multicriteria decision analysis (MCDA) method involving many hydrogeological parameters ranging from simple to complex parameters (Adiat et al., 2012; Adiat et al., 2013; Fashae et al., 2013). Similarly many approaches have been used to determine the aquifer protective capacity or aquifer vulnerability of an area. Overlay and index methods that combine specific physical characteristics that affect vulnerability, process-based methods consisting of mathematical models that approximate the behavior of substances in the subsurface environment (Adeyemo et al., 2015; Lathamani et al., 2015 and Javadi, et.al., 2017) and statistical methods that draw associations with 
areas where contamination is known to have occurred (Chen et. al., 2013 and Armengol, et. al., 2014). Geotechnical and geophysical methods have been used successfully for foundation beds competence investigations (Mesida, 1986, 1987; Adeyemo and Omosuyi, 2012).

\section{The Study area}

The study area is the proposed Foldot Ventures Nigeria Enterprises Potable Water Factory located at Chief Akin Omosebi layout off Ipinsallara road, near Akure, Ondo State, Nigeria (Figure 1). The area lies within 735840 $735910 \mathrm{~m}$ (Easting) and 809925 - $809990 \mathrm{~m}$ (Northing) in (WGS 84) Universal Traverse Mercatum Coordinates and the total surface area is about $1520 \mathrm{~m}^{2}$ (Figure 2). The surface elevation of the area varies between 415 and $416.5 \mathrm{~m}$ above sea level (Figure 2). The area falls within the tropical rainforest of the Southwestern Nigeria, which is characterized by wet and dry seasons with average rainfall of 1,000 - 1,400 mm (Adeyemo et al., 2017a) while the average daily temperature of the area range between 29 and $33{ }^{\circ} \mathrm{C}$ (Adeyemo et. al., 2017a). Groundwater recharge in this environment is mostly through rainfall and lateral base flow. Generally the study area is underlain by Precambrian Basement complex rocks (Igneous and Metamorphic) of Southwestern Nigeria (Rahaman, 1989). In tropical and equatorial regions, weathering processes create superficial layers (Adeyemo et al., 2015 and Adeyemo et al., 2017a) which often constitute reliable aquifers if significantly thick. Also the concealed basement rock may contain faults and fracture systems which may house groundwater. The area is underlain by rocks of Migmatite-Gneiss-Quartzite Complex (Figure 3) of Southwestern Nigeria (Adeyemo et. al., 2017a and Adeyemo et. al., 2017b).

\section{MATERIALS AND METHOD}

This study adopted the vertical electrical sounding (VES) techniques of the electrical resistivity method. The Schlumberger electrode configuration was adopted for the data acquisition (Koefoed, 1979 and Zohdy, 1975) with half-current electrode spread varying from minimum of $1 \mathrm{~m}$ to maximum of 100 to $150 \mathrm{~m}$. A total of 20 VES locations arrayed along five (5) traverses were occupied across the area (Figure 4). The field data were interpreted using the conventional partial curve matching techniques (Koefoed, 1979 and Zohdy, 1974) and the results were enhanced using Resist Version 1.0 software (Vander Velpen, 2005). A second order geoelectric parameter (longitudinal conductance) was also determined and the results were presented as a table and different maps.

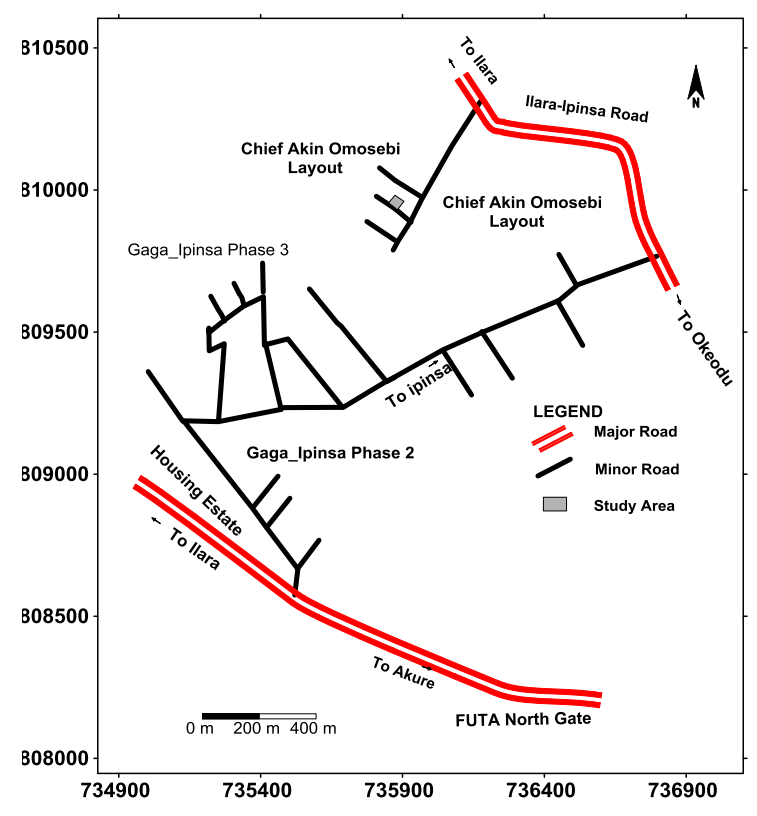

Figure 1: Layout map of Chief Akin Omosebi layout, Ipinsa Ondo State, Nigeria 
Nigerian Journal of Basic and Applied Science (June, 2017), 25(1): 101-110

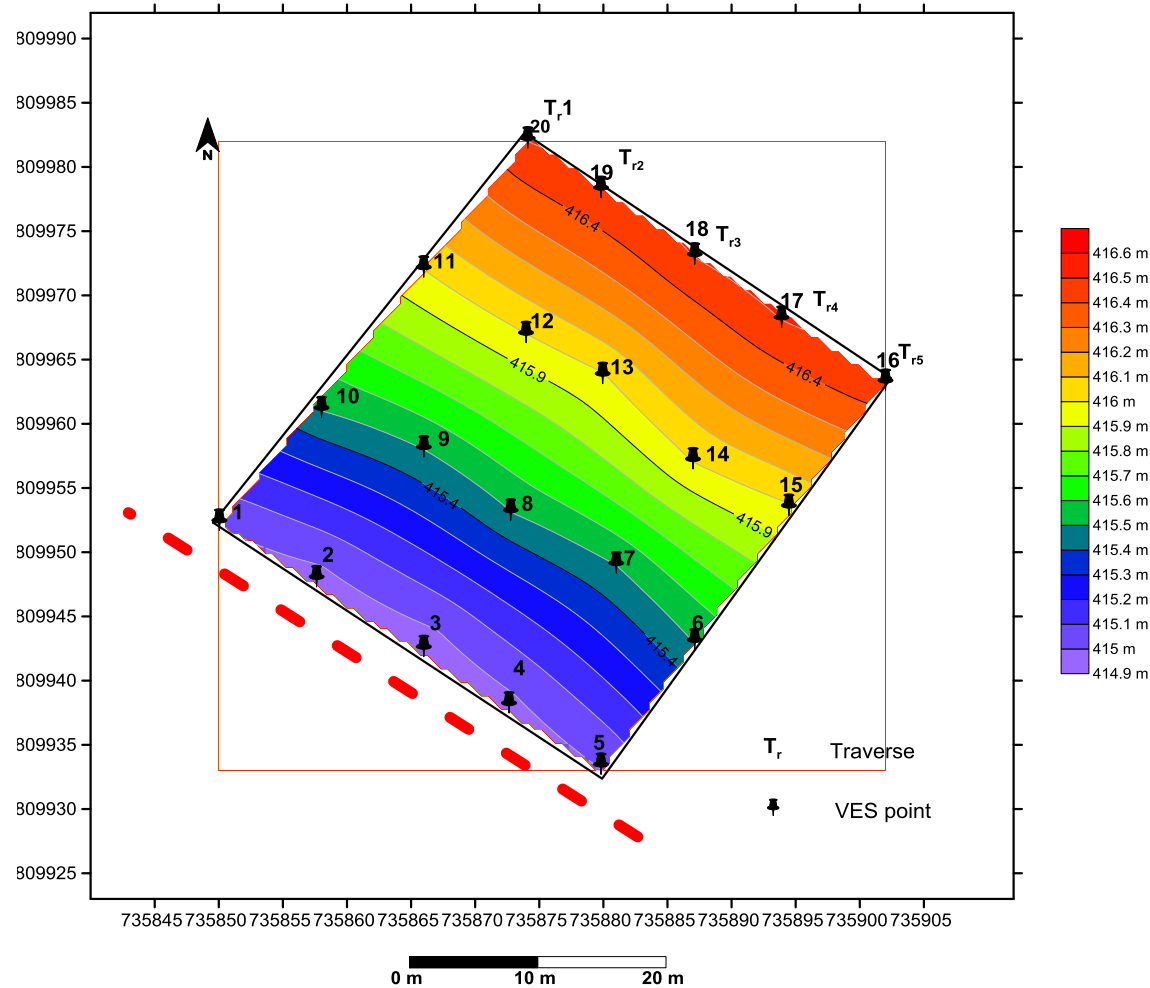

Figure 2: Topographic map of the study area (Foldot ventures site, Ipinsa Ondo State, Nigeria)

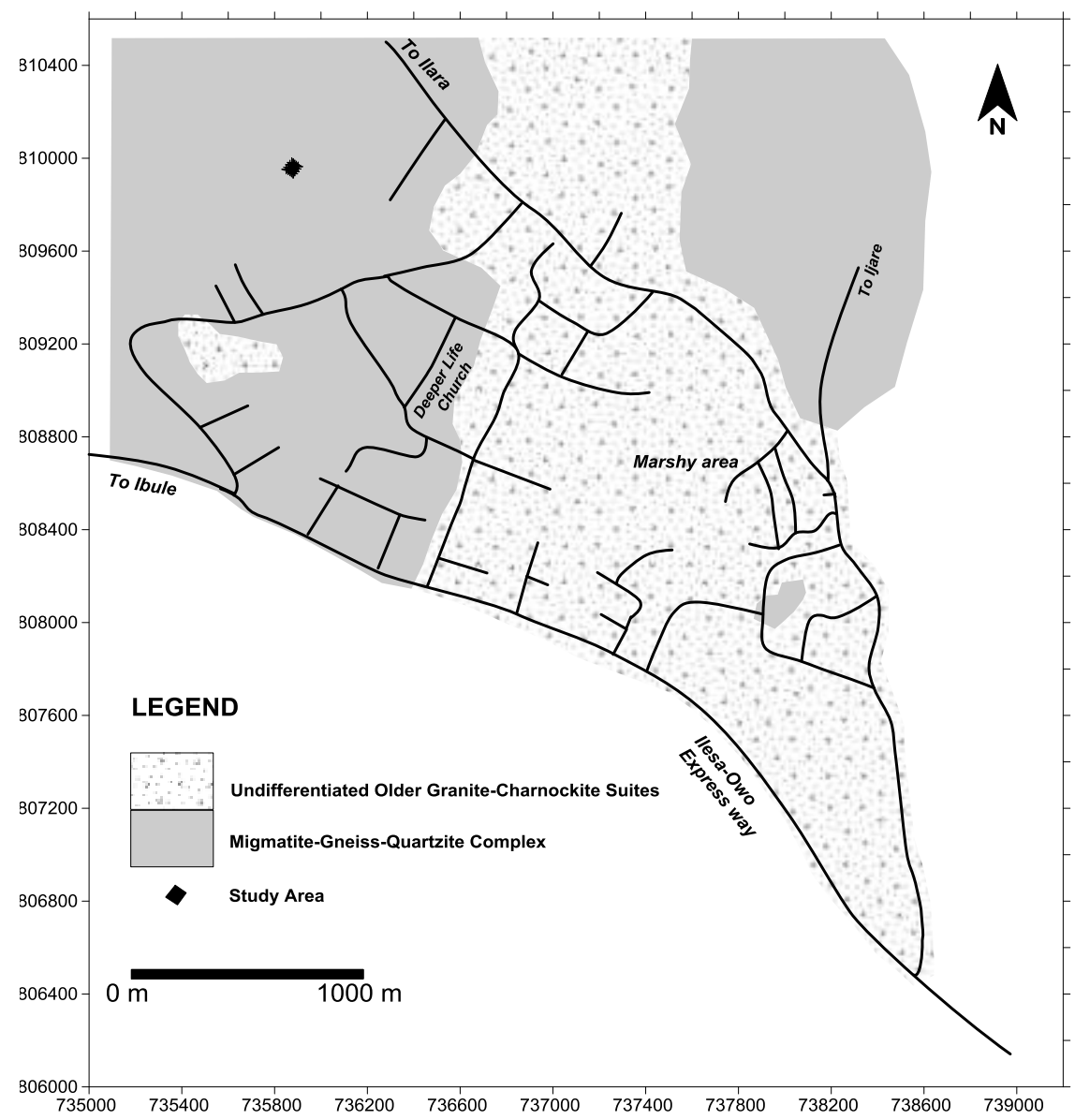

Figure 3: Simplified geological map of the area (Source: Adeyemo et. al., 2017a and 2017b) 


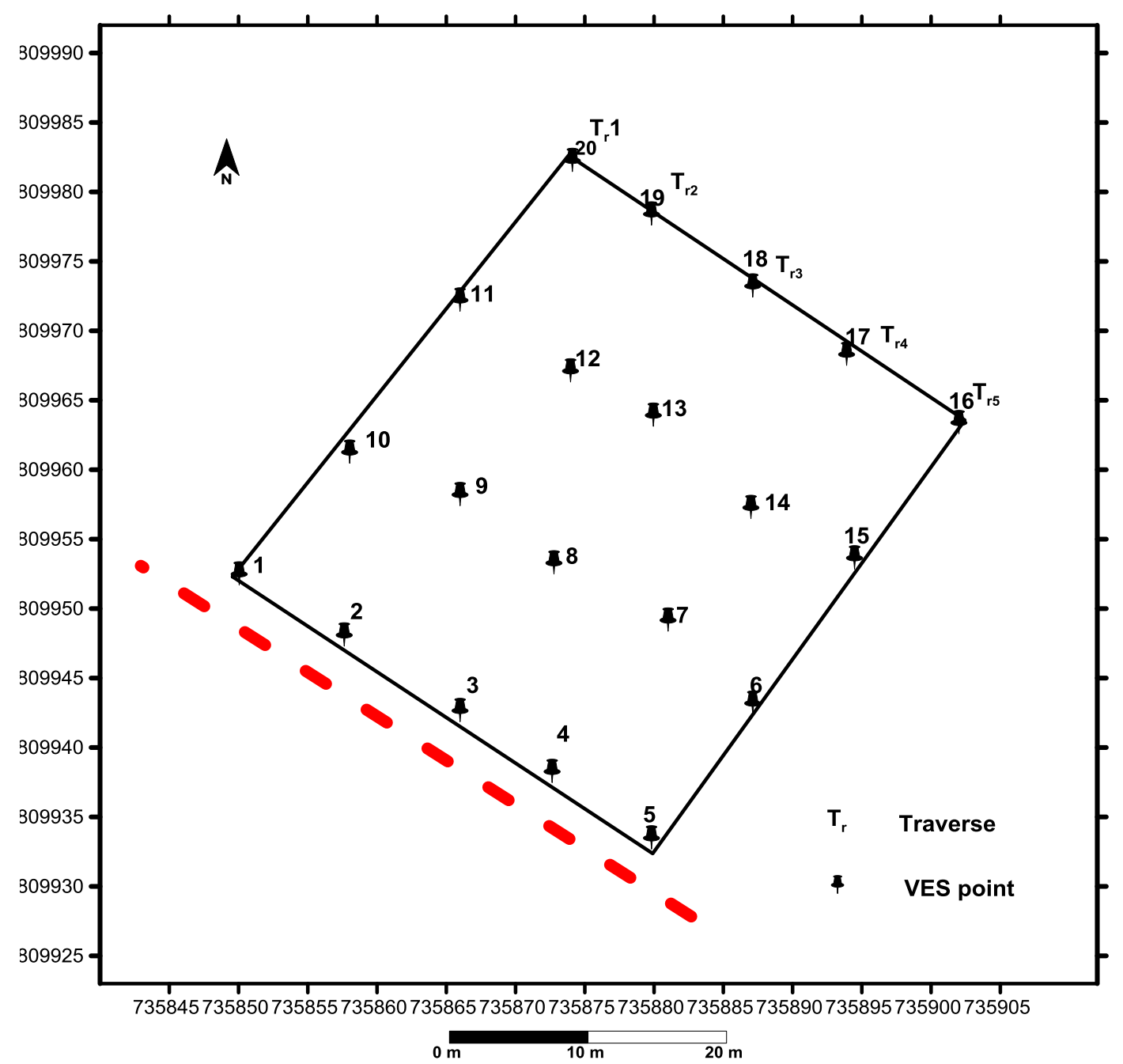

Figure 4: Basemap of the study area showing the VES locations

\section{RESULTS AND DISCUSSION}

The vertical electrical sounding (VES) results delineated three to four geoelectric layers across the study area. The $\mathrm{K}, \mathrm{KH}$ and $\mathrm{KQ}$ are the three sounding curve types delineated in the area (Table 1). The $K$ and $K Q$ curves are the predominant curve types in the area, their percentage of occurrence is $40 \%$ each, while the $\mathrm{KH}$ curve has $20 \%$ occurrence. The resistivity of the top soil, lateritic weathered layer, clayey sand weathered layer and weathered bedrock/fresh bedrock varies from 187 - 1212, 682 - 4164, 219 -1157 and 77 3525 ohm-m respectively.

\section{Groundwater Potential Evaluation}

The groundwater potential evaluation of the area was done by synthesizing the generated aquifer layer resistivity and thickness maps.
These two parameters; aquifer resistivity and thickness were considered to be sufficient for evaluating the groundwater potential of the area, because the area extent is small, they are within the same lithologic units and the elevation difference is very negligible (about 1.5 $\mathrm{m})$. The aquifer layers are essentially the clayey sand weathered layer (third geoelectric layer) and weathered bedrock (fourth geoelectric layer) and their resistivity vary from $77-457$ ohm-m across the study area (Table 1). The aquifer layer resistivity map (Figure 5a) shows that the western part of the area are characterized by higher resistivity indicating lesser water saturation (above $250 \mathrm{ohm}-\mathrm{m}$ ), while the eastern part of the area is characterized by lower resistivity which is indicative of moderate to high water saturation (80 - 250 ohm-m) based on earlier classification 


\section{Nigerian Journal of Basic and Applied Science (June, 2017), 25(1): 101-110}

(Adeyemo et. al., 2017a). The aquifer layer thickness map (Figure 5b) indicates that the whole area have thick aquifer layer (above 40 m) capable of yielding appreciable water quantities (Adeyemo et. al., 2017a). In order to synthesize the two maps, the groundwater potential map (Figure 5c) was generated using additive model first used by Chachadi (2005) and adapted by Adeyemo et al. (2017a). The contributions of the two parameters (aquifer resistivity and thickness) to groundwater potential were weighed as presented in table 2 .

Table1: Vertical Electrical Sounding (VES) Results

\begin{tabular}{ccccc}
\hline VES No & $\begin{array}{c}\text { Resistivity }(\Omega-m) \\
\rho_{1} / \rho_{2} / \rho_{3} \ldots \ldots \ldots \rho_{n}\end{array}$ & $\begin{array}{c}\text { Thickness }(\mathbf{m}) \\
\mathbf{d}_{1} / \mathbf{d}_{2} / \mathbf{d}_{3} / \ldots \ldots \ldots \mathbf{d}_{\mathbf{n}}\end{array}$ & $\begin{array}{c}\text { Curve Type } \\
\text { Depth to Aquifer } \\
\text { Layer }(\mathbf{m})\end{array}$ \\
\hline 1 & $426 / 2087 / 219 / 1808$ & $1.0 / 9.9 / 93.1$ & $\mathrm{KH}$ & 10.9 \\
2 & $387 / 2168 / 439 / 3525$ & $1.0 / 8.3 / 60.5$ & $\mathrm{KH}$ & 9.3 \\
3 & $393 / 2303 / 459 / 1357$ & $1.0 / 7.5 / 48.5$ & $\mathrm{KH}$ & 8.5 \\
4 & $1212 / 2010 / 406 / 1061$ & $1.5 / 7.7 / 52.0$ & $\mathrm{KH}$ & 9.2 \\
5 & $631 / 2972 / 664 / 108$ & $0.8 / 7.9 / 46.8$ & $\mathrm{KQ}$ & 55.5 \\
6 & $286 / 1386 / 226$ & $0.8 / 16.9$ & $\mathrm{~K}$ & 17.7 \\
7 & $187 / 2163 / 349 / 77$ & $0.7 / 3.4 / 42.1$ & $\mathrm{KQ}$ & 46.2 \\
8 & $838 / 4164 / 1157 / 234$ & $0.7 / 2.6 / 28.5$ & $\mathrm{KQ}$ & 31.8 \\
9 & $399 / 1902 / 457$ & $0.5 / 9.8$ & $\mathrm{~K}$ & 10.3 \\
10 & $432 / 1322 / 351$ & $0.7 / 16.7$ & $\mathrm{~K}$ & 17.4 \\
11 & $334 / 1591 / 356$ & $0.8 / 13.3$ & $\mathrm{~K}$ & 14.1 \\
12 & $373 / 1169 / 355$ & $0.9 / 16.5$ & $\mathrm{~K}$ & 17.4 \\
13 & $471 / 2381 / 1042 / 229$ & $0.6 / 2.9 / 26.8$ & $\mathrm{KQ}$ & 30.3 \\
14 & $272 / 2896 / 846 / 142$ & $0.5 / 3.1 / 29.1$ & $\mathrm{KQ}$ & 32.7 \\
15 & $402 / 3304 / 601 / 143$ & $0.8 / 3.9 / 31.4$ & $\mathrm{KQ}$ & 36.1 \\
16 & $661 / 2989 / 891 / 203$ & $1.3 / 6.2 / 18.1$ & $\mathrm{KQ}$ & 25.6 \\
17 & $357 / 682 / 843 / 164$ & $0.8 / 2.7 / 23.2$ & $\mathrm{KQ}$ & 26.7 \\
18 & $526 / 999 / 298$ & $1.1 / 23.8$ & $\mathrm{~K}$ & 24.9 \\
19 & $606 / 989 / 373$ & $0.8 / 12.8$ & $\mathrm{~K}$ & 13.6 \\
20 & $408 / 805 / 400$ & $1.2 / 10.0$ & $\mathrm{~K}$ & 11.2 \\
\hline
\end{tabular}

Note: the bold and italicized figures are the aquifer layers resistivity values.

Table 2: Indicators Relative Weights

\begin{tabular}{cll}
\hline S/N & Indicators & $\begin{array}{l}\text { Normalized } \\
\text { Weights }\end{array}$ \\
\hline 1 & $\begin{array}{l}\text { Aquifer Layer } \\
\text { Resistivity (ohm-m) }\end{array}$ & 5.5 \\
2 & $\begin{array}{l}\text { Aquifer Layer } \\
\text { Thickness (m) }\end{array}$ & 4.5 \\
\hline
\end{tabular}

The two (2) parameters were synthesized using the following relationship;

\footnotetext{
RT value $=\left\{\left[W t_{\text {resistivity }}{ }^{*} \mathrm{R} \mathrm{t}_{\text {resistivity }}\right]\right.$ $\left.\left[W t_{\text {thickhness }}{ }^{*} \mathrm{Rt}_{\text {thickness }}\right]\right\}$ (equation 1)

Where,

Wt $=$ Normalized Weight
}

\section{$\mathrm{Rt}=$ Rating}

The groundwater potential map (Figure $5 \mathrm{c}$ ) shows that the western part of the area is of high potential while the eastern part has very high potential. This indicates that boreholes meant for the purpose of commercial potable water supply in the study area should be sited within the eastern part of the area.

\section{Aquifer Overlying Layer Protective Capacity}

Another very important parameter to be considered before sitting a commercial borehole is the protective capacity of the aquifer overlying layer(s). The depth to the aquifer layers range from $9.2-55.5 \mathrm{~m}$ and all things 
been equal the thicker the overlying layer the more the protective capacity. The overlying protective capacity was determined using the aquifer overlying layer(s) longitudinal conductance as done in previous works (Oladapo, 2004; Aweto, 2011 and Oni et al., 2017). The aquifer overlying layer(s) longitudinal conductance was determined using the following relationship;

$$
\mathrm{S}=\sum_{i=1}^{n} \frac{h i}{\rho i}=\frac{h 1}{\rho 1}+\frac{h 2}{\rho 2}+\frac{h 3}{\rho 3}+\cdots+\frac{h n}{\rho n}
$$

(equation 3)

Where,

$h_{i}=$ layer thickness $(m)$

$\rho_{i}=$ layer resistivity (ohm-m)

While, for $\mathrm{n}$ layers the total longitudinal conductance (mhos) is:

\section{Foundation Beds Competence}

The aquifer overlying layer(s) longitudinal conductance map (Figure 6) reveals that the aquifer layer(s) in most part of the study area are overlained by materials of very low to moderate protective capacity (less than 0.1 mhos). This suggest that the the aquifer layer(s) in the area are susceptible to pollution (Oladapo, 2004; Aweto, 2011; Adeyemo et. al., 2015 and Oni et. al., 2017). Therefore standard practice must be followed in carring out borehole completion in this area. Any borehole constructed in the area must be properly grouted and about $5 \mathrm{~m}$ radius of the surface around the borehole should be covered with concrete to prevent percolation of possible pollution from the surface.
The VES results (Table 1) shows that the second geoelectric layer (lateritic weathered layer) with resistivity range of $682-4164 \mathrm{ohm}$ $\mathrm{m}$ is geotechnically competent (Habeeb et al., 2012) and hence can serve as appropriate foundation bed in the study area, however depth to this layer varies from one VES location to the other. The VES result was therefore presented as depth slice maps at three different surfaces $(0.5,0.75$ and $1.0 \mathrm{~m})$. As expected the depth slice maps (Figures 7a-c) shows improvement in the subsurface competence with increase in depth, and that the appropriate depth for foundation in the study area is minimum of $1.0 \mathrm{~m}$. 
Nigerian Journal of Basic and Applied Science (June, 2017), 25(1): 101-110

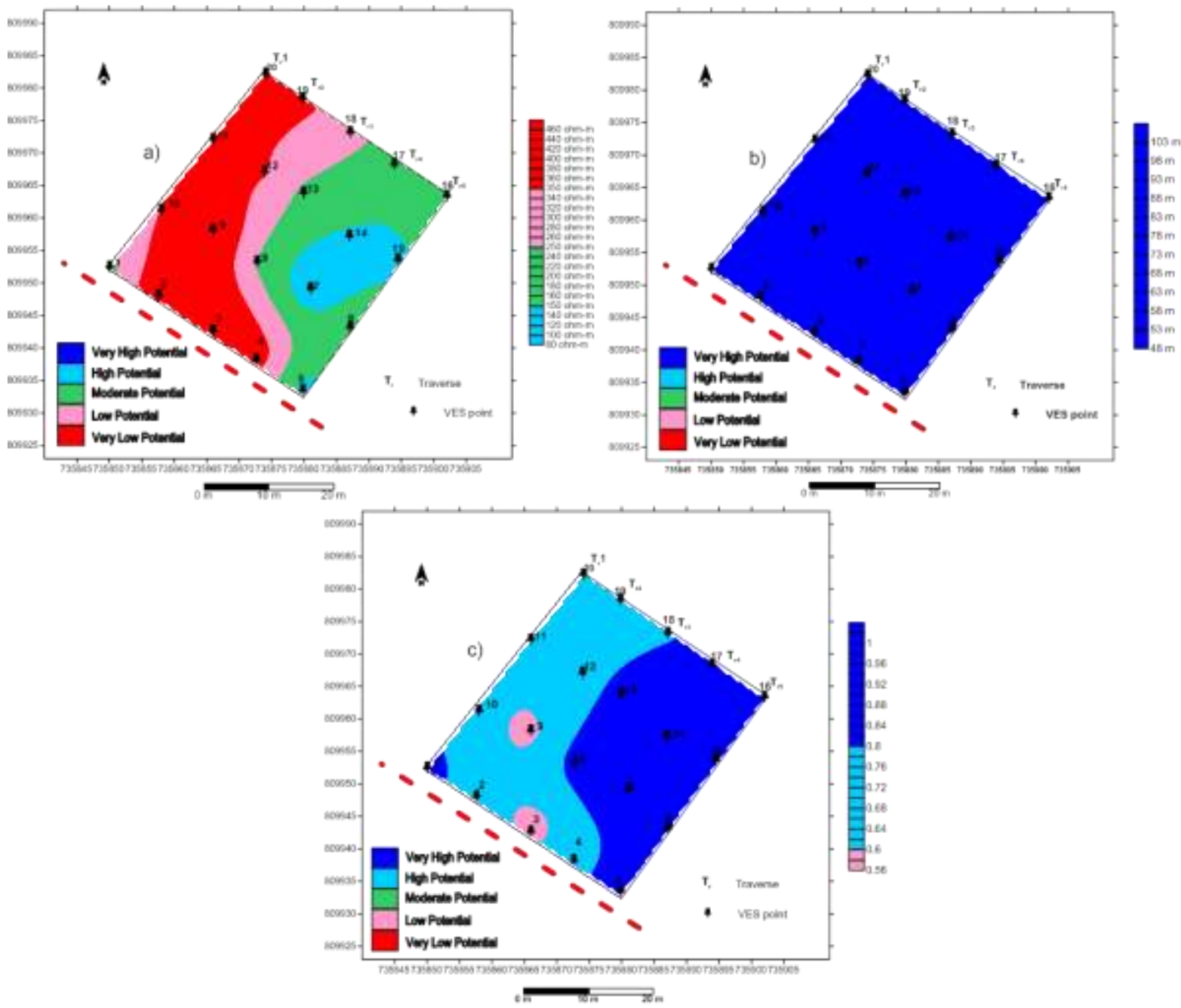

Figures 5: (a) Aquifer layer resistivity map (b) Aquifer layer thickness map and (c) Groundwater potential map of the area

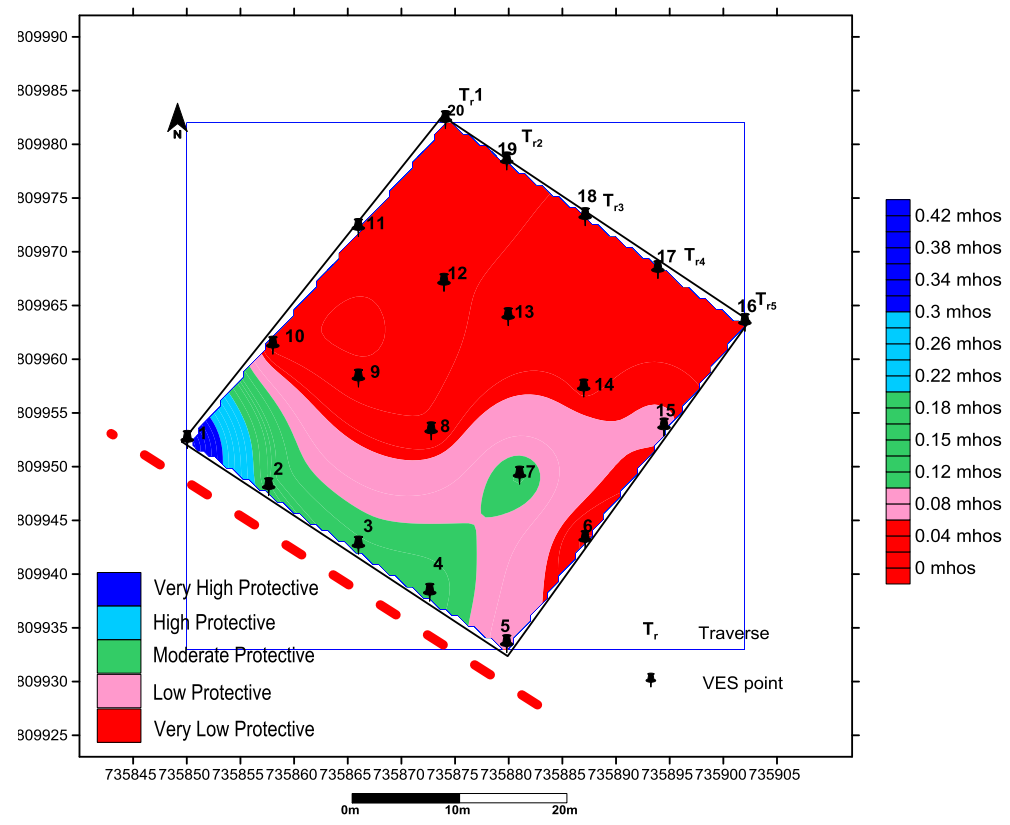

Figure 6: Aquifer protective capacity map of the area 


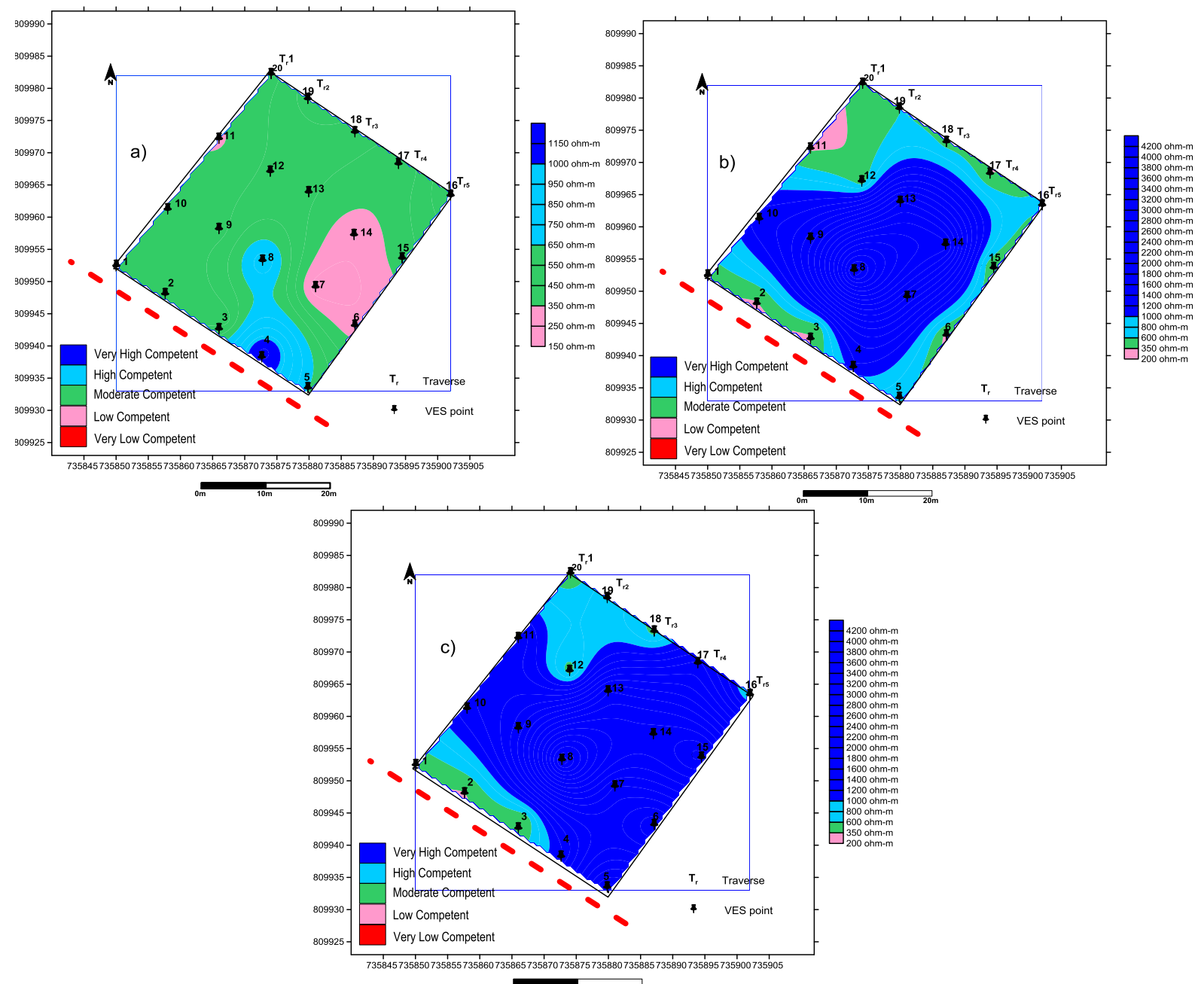

Figures 7: Isoresistivity maps (a) at depth slice of $0.5 \mathrm{~m}$, (b) at depth slice of $0.75 \mathrm{~m}$ and (c) at depth slice of $1.0 \mathrm{~m}$

\section{CONCLUSION}

The work was carried out to determine the suitability of the study area as a good location for sitting the proposed Foldot Ventures Nigeria Enterprises Potable Water factory. The results discussion showed that the study area is characterized by high groundwater potential and competent subsurface layers that can serve as foundation bed. However the aquifer layer must be well protected from pollution and contamination since the overlying layer(s) longitudinal conductance is less than 1.0 mhos which indicates that aquifer units in the study area are vulnerable to surface pollution. Therefore any borehole constructed in the area must be properly grouted and about $5 \mathrm{~m}$ radius of the surface around the borehole should be covered with concrete to prevent possible pollution from the surface.

\section{ACKNOWLEDGMENTS}

The assistance rendered by Omotosho, 0 . and Olabomi, A. during the field work was well appreciated.

\section{REFERENCES}

Adeyemo, I.A. and Omosuyi, G.O., 2012.

Geophysical Investigation of Road

Pavement Instability along part of Akure-

Owo Express Way, Southwestern Nigeria.

American Journal of Scientific and Industrial Research. 3(4):191-197.

Adeyemo, I.A., Mogaji, K.A, Olowolafe, T. S and Fola-Abe, A. O., 2015. Aquifer vulnerability Modelling from Geoelectrical Derived Parameters - Case of GIS-Based GODA Model Approach. International 


\section{Nigerian Journal of Basic and Applied Science (June, 2017), 25(1): 101-110}

Journal of Petroleum and Geoscience Engineering, 3(2): 69 - 80.

Adeyemo, I.A., Omosuyi, G.O., Ojo, B.T. and Adekunle, A., 2017a. Groundwater Potential Evaluation in a Typical Basement Complex Environment Using GRT Index A Case Study of Ipinsa-Okeodu Area, Near Akure, Nigeria. Journal of Geoscience and Environment Protection (GEP), Scientific Research, 5(3): 240 251, doi.org/10.4236/gep.2017.53017

Adeyemo, I.A., Ojo, B.T. and Raheem, W.O., 2017b. A Comparison of Thickness and Depth Resolution Power of Wenner and Schlumberger Arrays: A Case Study of Temidire Quarters, Akure, Nigeria. Journal of Geoscience and Environment Protection (GEP), Scientific Research Publishing, 5(3): 233 - 239.

Adiat, K.A.N., Nawawi, M.N.M. and Abdullah, K., 2012. Assessing the Accuracy of GISBased Elementary Multi criteria Decision Analysis as a Spatial Prediction Toll - A case of Predicting potential Zones of Sustainable groundwater Resources. Journal of hydrology, Elsevier, 440 - 441 (75 - 89), 130 - 144.

Adiat, K.A.N., Nawawi, M.N.M. and Abdullah, K., 2013. Application of Multi-Criteria Decision Analysis to Geoelectric and Geologic Parameters for Spatial Prediction of Groundwater Resources and Aquifer Evaluation. Pure and Applied Geophysics, Springer. 170(3): 156 - 174.

Akintorinwa, O.J. and Olowolafe T.S., 2013. Geoelectric Evaluation of Groundwater Prospect within Zion Estate, Akure, Southwest, Nigeria. International Journal of Water Resources and Environmental Engineering. 5(1):12 - 28.

Amadi, A. N., Nwawulu C. D., Unuevho C. I. and Ako, T. A., 2011. Evaluation of the Groundwater Potential of Pompo Village, Gidan Kwano, Minna Using Vertical Electrical Resistivity Sounding. British Journal of Applied Science \& Technology 1(3):53 - 66

Armengol, S., Sanchez-Villa, X. and Folch, A., 2014. An Approach to Aquifer Vulnerability
Including in a Spatial Random Function Framework. Elsevier, Journal of Hydrology, Science Direct, 517, 889 900.

Aweto, K.E. (2011). Aquifer Vulnerability Assessment at Oke-lla area, Southwestern Nigeria. international Journal of the Physical Sciences, 6(33): $7574-7583$.

Chachadi, A. G. Seawater intrusion mapping using modified GALDIT indicator modelcase study in Goa. Jalvigyan Sameeksha, 20: 29 - 45 .

Chen, S., Jang, C. and Peng, Y., 2013, Developing a Probability-Based Model of Aquifer Vulnerability in an Agricultural Region. Elsevier, Journal of Hydrology, Science Direct, 486, 494 - 504.

Fashae, O.A., Tijani, M.N., Talabi, A.O. and Adedeji, O.I., 2013. Delineation of Groundwater Potential Zones in the Crystalline Basement Terrain of SWNigeria: an Integrated GIS and Remote Sensing Approach. Applied Water Science, Springer Link. (4). 19 - 38.

Filippini, M., Stumpp, C., Nijenhuis, I., Richnow, H.H. and gargini, A., 2015. Evaluation of aquifer Recharge and Vulnerability in an Alluvial Lowland Using Environmental Tracers. Elsevier, Journal of Hydrology, Science Direct, 529, 1657 - 1668.

Habeeb, A.Q., Olabambo, A.A. and Oladipupo, S.O. (2012): Investigation of the Geotechnical Engineering Properties of Laterite as a Subgrade and Base Material for Road Constructions in Nigeria. Journal of Civil Engineering Research of International Institute for Science, Technology and Education (IISTE), 2(8): 23 - 31.

Jang, C. and Chen, S., 2015. Integrating Indicator-Based Geostastitical Estimation and Aquifer Vulnerability of Nitrate-N for Establishing Groundwater Protection Zones. Elsevier, Journal of Hydrology, Science Direct, 523, 441 - 451.

Javadi, S., Hashemy, S.M., Mohammadi, K., Howard, K.W.F. and Neshat, A., 2017. Classification of Aquifer Vulnerability 
Unsing K-Means Cluster Analysis. Elsevier, Journal of Hydrology, Science Direct, 517, 27 - 37.

Koefoed, O. (1979).Geosounding Principles 1. Resistivity Measurements. Elsevier Scientific Publishing, Amsterdam, Netherlands, 275p.

Lathamani, R., Janardhana, M.R., Mahalingam, B. and Suresha, S., 2015. Evaluation of aquifer Vulnerability Using Drastic Model and GIS: A Case Study of Mysore City, Karnataka, India. Elsevier, Science Direct, Aquatic Procedia, 1031 - 1038.

Mesida, E.A., 1986. Some Geotechnical Properties of Residual Mica Schist Derived Subgrade and Fill Materials in the llesha Area, Nigeria, 33, 14 - 17.

Mesida, E.A., 1987. The Relationship Between the Geology and the Lateritic Engineering Soils in the Northern Environs of Akure, Nigeria, Bulletin of the International Association of Engineering Geology, 35, $65-69$.

Mogaji, K.A., Omosuyi, G.O., and Olayanju, G.M., 2011. Groundwater System Evaluation and Protective Capacity of Overburden Material at Ile-Oluji, Southwestern Nigeria. Journal of Geology and Mining Research, 3(1):294-304.

Oladapo, M.I, Mohammed, M.Z., Adeoye, O.O. and Adetola, B.A., 2004. Geoelectric Investigation of Ondo State Housing Estate, ljapo Akure, Southwestern Nigeria. Journal of Mining and Geology, 40(1): 41 48.
Olayanju, G.M., Ayuk, M.A. and Adelusi, A.O., 2011. Geotechnical Mapping of the Groundwater Regime around the Federal Polytechnic, Ado-Ekiti, Southwestern Nigeria. Journal of Geology and Mining Research, 3(8):201 - 210.

Oni, T.E. Omosuyi, G.O. and Akinlalu, A.A., 2017. Groundwater Vulnerability Assessment using Hydrogeologic and Geoelectric Layer Susceptibility Indexing at Igbara-Oke, Southwestern Nigeria. Journal of Astronomy and Geophysics, 6: $452-458$.

Rahaman, M.A. (1989). Review of the Basements Geology of Southwestern Nigeria. In Kogbe, C.A., (ed.) Geology of Nigeria, 39 - 56.

Vander Velpen, B. P. A., 2004. WinRESIST Software Version 1.0. ITC, IT-RSG/GSD, Delft, Netherlands.

Zohdy, A.A.R., Eaton, G.P. and Mabey, D.R. (1974). Application of Surface Geophysics to Ground-Water Investigations, In Techniques of Water-Resources Investigations of the United States Geological Survey, Book 2, Chapter D1. $63 p$. 